\title{
EFFECTIVENESS OF GUIDANCE AND COUNSELING SERVICES BY USING THE APPLICATIONS INSTRUMENTATION AND ACTIVITY DATA SET IN SMA NEGERI 1 METRO LESSON 2009/2010
}

\author{
AGUS WIBOWO \\ Universitas Muhammadiyah Metro \\ Email:Bowokhoirunnas_khairunnasgcc@rocketmail.com
}

\begin{abstract}
Implementation of guidance and counseling services should be based on the needs and problems of students, so the effectiveness of the service will be achieved to the fullest. But the reality is a lot of implementation of guidance and counseling services in schools, do not notice it. So that the completion of the problems experienced by students sama.Berangkat always use the services of this, the research level of effectiveness of guidance and counseling that implementation has been using the application activity instrumentation and data sets as the basis for an implementation of the service. The method used is a qualitative research subjects that teachers BK and Students at SMA Negeri 1 Metro. Data collection technique through interview, observation and documentation. Research results show that by utilizing activity instrumentation applications and data sets, the counseling services have a high level of effectiveness. In carrying out the service, BK teachers can identify problems and needs experienced by students, so that the efforts of the assistance provided to be more precise, and problem students can terentaskan optimally.
\end{abstract}

Keyword: Guidance and Counseling, Instrumentation Applications, Data Association

\section{PENDAHULUAN}

Pendidikan mengambil peranan penting dan memberikan konstribusi yang sangat besar dalam upaya peningkatan kualitas sumber daya masnusia. Dengan pendidikan yang dilaksanakan secara benar, profesional, dan berkualitas, akan menghasilkan peserta didik/sumber daya manusia yang berkualitas. Bagi bangsa Indonesia, kontribusi pendidikan yang diharapkan bagi perkembangan peserta didik termaktub dalam Undang-Undang No. 20 tahun 2003 Bab II pasal 3 ayat 1 tentang Sistem Pendidikan Nasional yang berbunyi sebagai berikut:

Pendidikan nasional berfungsi mengembangkan kemampuan dan membentuk watak serta peradaban 
bangsa yang bermartabat dalam rangka mencerdaskan kehidupan bangsa, bertujuan untuk berkembangnya potensi peserta didik agar menjadi manusia yang beriman dan bertakwa kepada Tuhan Yang Maha Esa, berakhlak mulia, sehat, cakap, kreatif, mandiri, dan, menjadi warga Negara yang demokratis serta bertanggung jawab.

Fungsi dan tujuan pendidikan tersebut mengandung suatu harapan terbentuknya karakter pribadi individu (peserta didik) yang memiliki kepribadian yang baik, berakhlak, bertakwa, dan bertanggung jawab.

Usaha untuk mencapai perkembangan peserta didik yang optimal, bukan hanya tanggung jawab guru semata (guru mata pelajaran), melainkan semua pihak dalam sekolah memiliki tanggung jawab yang sama untuk tercapainya tujuan pendidikan yang sebenar-benarnya. Semua pihak harus mampu berperan sesuai dengan bidangnya dan selalu bekerja sama demi tercapainya perkembangan peserta didik yang optimal.

Permendiknas No.22/2006 tentang KTSP, membagi tugas dan tanggung jawab pihak-pihak yang terkait dalan lembaga pendidikan sesuai dengan kemampuannya,yaitu:
1. Guru bertugas menyampaikan mata pelajaran dan muatan lokal.

2. Konselor sekolah melaksanakan pelayanan konseling

3. Pembina Khusus melakukan kegiatan ekstarakurikuler.

Berdasarkan Permendiknas di atas, sangat jelas bahwa bimbingan dan konseling merupakan salah satu komponen yang terpenting dalam usaha pencapaian tujuan pendidikan yang telah diamanatkan oleh undang-undang. Dan pada dasarya tujuan dari layanan bimbingan dan konseling selaras dengan tujuan pendidikan tersebut.

Pelayanan BK di sekolah diarahkan pada ketercapaian tujuan pendidikan dan tujuan pelaksanaan konseling. Sebagai salah satu lembaga pendidikan, sekolah membutuhkan pelayanan BK dalam penyelenggaraan dan peningkatan kondisi kehidupan di sekolah demi tercapainya tujuan pendidikan yang berjalan seiring dengan visi profesi konseling yaitu terwujudnya kehidupan kemanusiaan yang membahagiakan melalui tersedianya pelayanan bantuan dalam memberikan dukungan perkembangan dan pengentasan masalah agar individu berkembang secara optimal, mandiri 
dan bahagia (Prayitno dan Erman Amti, 2004: 13) .

Parson dalam prayitno (2004: 93) menyatakan bahwa bimbingan adalah bantuan yang diberikan kepada individu untuk dapat memilih, mempersiapkan diri, dan memangku suatu jabatan serta mendapat kemajuan dalam jabatan yang dipilihnya itu. Dalam pengertian tersebut Parson lebih menekankan pelaksanaan bimbingan dimaksudkan membantu individu dalam pemilihan karir atau pekerjaan.

Bimbingan merupakan proses pemberian bantuan kepada individu yang dilakukan secara berkesinambungan, dan bukan hanya bersifat insidential. Natawidjaya (Prayitno, 1994: 19) mendefinisikan bimbingan yaitu:

sebagai suatu proses pemberian bantuan kepada individu yang dilakukan secara berkesinambungan supaya individu tersebut dapat memahami dirinya sendiri, sehingga ia sanggup mengarahkan dirinya dan dapat bertindak secara wajar, sesuai dengan tuntutan dan keadaan lingkungan sekolah, keluarga, masyarakat dan kehidupan pada umumnya.

Merujuk beberapa pendapat tentang konsep bimbingan, di maknai bahwa bimbingan tidak dilakukan hanya sekali saja, namun juga dilakukan secara berkesinambungan dimana muaranya adalah konseli mampu secara mandiri memahami dirinya, dan mampu mengarahkan dirinya kepada kehidupan yang kebih efektif.

Konsep konseling memiliki makna yang berbeda dengan bimbingan, walaupun terdapat beberapa teori ada yang menyebutkan pelayanan konseling, pada dasarnya sudah mencakup proses bimbingan, namun agar lebih jelas akan konsep konseling Juntika (2006: 10) memberikan pengertian konseling sebagai upaya membantu individu melalui proses interaksi yang bersifat pribadi antara konselor dan konseli agar konseli mampu memahami diri dan lingkungannya, mampu membuat keputusasn dan menentukan tujuan beedasarkan nilai yang diyakininya, sehinggga konseli merasa bahagia dan efektif prilakunya.

Pendapat diatas, menggambarkan bahwa konseling dilakukan oleh individu yang memiliki kompetensi dibidang konseling, yaitu konselor. Senada dengan pendapat diatas, Maclean (dalam Prayitno, 2004: 100) memberikan pengertian konseling adalah: 
suatu proses yang terjadi dalam hubungan tatap muka antara seorang individu yang terganggu oleh karena masalah-masalah yang tidak dapat diatasinya sendiri dengan seorang pekerja profesional, yaitu orang yang telah terlatih dan berpengalaman membantu orang lain mencapai pemecahan-pemecahan terhadap berbagai jenis kesulitan pribadi.

Maclean menyebutkan pihak yang membantu dalam proses konseling sebagai pihak yang profesional, yaitu pihak yang terlatih dan berpengalaman. Dan tujuan dri proses tersebut adalah agar invidvu mampu mengambil keputusan yang terbaik untuk dirinya sendiri.

Winkel (2005:34) mendefinisikan konseling sebagai serangkaian kegiatan paling pokok dari bimbingan dalam usaha membantu konseli/klien secara tatap muka dengan tujuan agar klien dapat mengambil tanggung jawab sendiri terhadap berbagai persoalan atau masalah khusus. Untuk keberhasilan konseling, seorang guru pembimbing/konselor harus memiliki modal personal yang meyakinkan, karena proses konseling yang efektif bila dilakukan secara tatap muka, atau dengan kontak langsung dengan klien atau peserta didik
Efektifitas layanan bimbingan dan konseling merupakan tingkat keberhasilan/ketercapaian tujuan dari layanan bimbingan dan konseling yang dilaksanakan. Keefektifan layanan bimbingan dan konseling terhadap peserta didik, dapat dilihat dari beberapa indikator, seperti peserta didik secara efektif mampu mengaktualisasikan dirinya dalam dalam setiap dimensi kehidupannya, mampu secara efektif mengatasi permasalahan yang dihadapi, pengembangan diri yang optimal, dan mampu merencanakan masa depan secara realistik.

Akan tetapi untuk mencapai tingkat efektifitas pelayanan bimbingan dan konseling adalah hal yang sulit. Dalam penerapan bimbingan dan konseling disekolah, masih banyak terdapat guru pembimbing melaksanakan layanan yang tidak memperhatikan tingkat efektivitas layanan. Ketidakefektifan layanan bimbingan dan konseling dapat terlihat dari beberapa aspek, antara lain:

1. program bimbingan dan konseling dibuat tidak sesuai dengan kebutuhan peserta didik. 
2. layanan yang diberikan belum membantu siswa mencapai perkembangan dan kemandirian diri yang optimal.

3. masih timbulnya permasalahan dari peserta didik dalam aspek pribadi, sosial, belajar, dan karir.

4. ketidakmampuan peserta didik dalam menentukan dan mengambil keputusan untuk merencanakan masa depannya.

Salah satu faktor penyebab ketidakefektifan layanan bimbingan yang dilaksanakan adalah dalam merencanakan dan memberikan layanan tidak memperhatikan kondisi/data diri peserta didik.. Layanan diberikan hanya berdasarkan program yang disusun untuk kebutuhan "administrasi" bimbingan dan konseling.

Salah satu upaya yang dapat digunakan untuk meningkatkan efektifitas pelayanan konseling yaitu dengan menggunakan kegiatan aplikasi instrumentasi dan himpunan data. Kegiatan aplikasi instrumentasi merupakan salah satu kegitan pendukung ari layanan bimbingan dan konseling. Mulyadi (2003: 27)

mendefinisikan kegiatan aplikasi instrumentasi sebagai kegiatan pendukung bimbingan dan konseling untuk mengumpulkan data dan keterangan peserta didik (klien), keterangan lingkungan peserta didik, dan lingkungan yang lebih luas. Pengumpulan data ini dapat dilakukan melalui berbagai instrumen, baik tes dan non tes.

Secara umum tujuan aplikasi instrumentasi adalah diperolehnya data hasil pengukuran terhadap kondisi tertentu klien (Prayitno, 2004:3). Secara khusus pelaksanaan kegiatan aplikasi istrumentasi lebih kearah fungsi pemahaman. Materi yang hendak diungkap dalam pelaksanaan aplikasi instrumentasi jenisnya bermacammacam, sesuai dengan alat ukur/instrumen yang digunakan. Akan tetapi, khusus dalam pelaksanaan layanan bimbingan dan konseling, materi yang ingin diungkap pada umumnya menyangkut diri individu. Secara rinci, Prayitno (2004: 5) materi yang berkenaan dengan bimbingan dan konseling, yang perlu untuk diungkap antara lain:

a) Kondisi fisik individu; keadaan jasmaniah dan kesehatan

b) Kondisi dasar psikologis; potensi dasar, bakat, minat, dan sikap. 
c) Kondisi dinamik-fungsional psikologis.

d) Kondisi kegiatan dan hasil belajar.

e) Kondisi hubungan sosial.

f) Kondisi keluarga dan lingkungan.

g) Kondisi arah pengembangan dan karir.

h) Permasalahan yang potensial dan/atau sedang dialami.

Setelah melakukan kegiatan instrumentasi, data yang telah dianalisis harus dikumpulkan/ diadministrasikan sehingga pemanfaatannya akan mudah. Kegiatan tersebut disebut sebagai himpunan data. Kegiatan himpunan data adalah kegiatan pendukung bimbingan dan konseling untuk menghimpun seluruh data dan keterangan yang relevan dengan keperluan pengembangan peserta didik (Purwoko, 2003: 28). Kegiatan himpunan data perlu diselenggarakan secara berkelanjutan, sistematis, komphrehensif, terpadu, dan sifatnya tertutup.

Prayitno dan Amti (2004:315) menyatakan penyelenggaraan himpunan data merupakan kegiatan pendukung layanan konseling untuk menghimpun seluruh data dan keterangan yang relevan dengan keperluan pengembangan klien. Dalam pelaksanaan kegiatan himpunan data, terdapat bebrapa tujuan yang hendak dicapai. Tujuan tersebut terbagi menjadi tujuan umum dan tujuan khusus (Prayitno:2004) sebagai berikut:

1. Tujuan Umum

Dalam kegiatan himpunan data, secara umum bertujuan unutk menyediakan data dalam kualitas yang baik dan lengkap untuk menunjang penyelenggaraan pelayanan konseling sesuai dengan kebutuhan klien dan individuindividu lain yang menjadi tanggung jawab guru pembimbing/konselor.

2. Tujuan khusus dari himpunan data adalah diperolehnya pemahamam secara utuh tentang kondisi peserta didik. Scara rinci tujuan khusus tersebut adalah:

a) Untuk pencegahan terhadap timbulnya permasalah peserta didik yang mungkinakan dialami

b) Mendukung terentaskannya permasalah yang telah dialami oleh peserta 
didik (fungsi dukungan fasilitas juga cukup pengentasan)

mendukung.

c) Sebagai pengembangan

Bimbingan dan Konseling di layanan dan keefektifan layanan yang akan diberikan kepada peserta didik (fungsi pengembangan dan pemeliharaan).

Kegiatan Aplikasi instrumentasi dan himpunan data yang dilakukan secara benar, dan melalui perencanaan yang baik sangat mendukung keberhasilam pelayanan konseling yang dilaksanakan oleh guru BK. Melalui kegiatan aplikasi instrumentasi dan himpunan data, maka dapat meminimalisir terjadinya kegiatan bimbingan dan konseling yang kurang efektif, dan dapat meningkatkan kepercayaan semua pihak terhadap keberadaan pelayanan konseling dalam dunia pendidikan.

SMA N1 Metro merupakan salah satu sekolah favorit di Kota Metro. Sebagai sekolah favorit, SMA N1 memiliki fasilitas yang memadai untuk mendukung keberhasilan proses pendidikan. Pelayanan Bimbingand an Konseling di SMA N1 juga telah berjalan dengan cukup baik, selain didukung oleh guru BK yang berkualitas dan berpengalaman, SMA N1 Metro memiliki fasilitas penunjang kegiatan BK yang memadai, termasuk instrumen pendukung datanya. Selain itu berbagai instrumen tersebut telah dilakukan kegiatan instrumentasi dan himpunan data. Kegiatan aplikasi instrumentasi dan himpunan data memiliki peran yang sangat besar dalam mendukung pelaksanaan pelayanan bimbingan dan konseling. Melalui kegiatan aplikasi instrumentasi dan himpunan data akan diperoleh data tentang masalah dan kebutuhan siswa yang berguna dalam pelaksanaan pelayanan bimbingan dan konseling.

Berdasarkan uraian tersebut, penelitian diberi judul," Tingkat Efektivitas Layanan Bimbingan dan Konseling dengan Memanfaatkan Kegiatan Aplikasi Instrumentasi dan Himpunan Data di SMA Negeri 1 Metro Tahun Pelajaran 2009/2010". Fokus penelitian yaitu: 1) Pelaksanaan kegiatan aplikasi instrumentasi dan himpunan data di SMA N 1 Metro 2) Manfaat kegiatan aplikasi instrumentasi dan himpunan data dalam peningkatan efektivitas layanan bimbingan dan 
konseling di SMA N 1 Metro 3) Tingkat

efektifitas layanan bimbingan dan konseling melalui pemanfaatan aplikasi instrumentasi dan himpunan data SMA N 1 Metro.

\section{METODE PENELITIAN}

Metode penelitian yang digunakan adalah metode penelitian kualitatif. Lokasi penelitian yaitu SMA N1 Kota Metro, waktu penelitian adalah pada bulan Februari sampai Juli 2010. Sumber data adalah guru BK dan siswa SMA N1 Metro. Teknik yang digunakan untuk menentukan sumber data penelitian yaitu Snowball Sampling. Teknik yang digunakan untuk mengumpulkan data yaitu wawancara, observasi, dan dokumentasi. Untuk melakukan uji keabsahan data, digunakan teknik triangulasi. Setelah data terkumpul dan dilakukan uji keabsahan maka selanjutnya dilakukan analisis dengan cara: a) Reduksi Data; mengelompokan dan memilih data-data yang diperoleh agar sesuai dengan fokus penelitian,b) Display Data; menyajikan data dalam bentuk matrik naratif. Tujuannya agar diperoleh gambaran secara menyeluruh tentang data penenlitian yang telah diperoleh, dan c) Membuat kesimpulan

\section{HASIL DAN PEMBAHASAN}

\section{Pelaksanaan kegiatan aplikasi} instrumentasi dan himpunan data di SMA N 1 Metro

Kegiatan aplikasi instrumentasi dan himpunan data di SMA Negeri 1 diawali dengan kegiatan perencanaan kegiatan. Perencanan kegiatan instrumentasi antara lain meliputi persiapan instrumen, personel, tujuan kegiatan, dan waktu pelaksanaan kegiatan. Kelengkapan instrumen terdiri dari jenis instrumen yang digunakan. Berikut petikan wawancara ( $\mathrm{W} .3 / \mathrm{I} / 40)$, "Instrumen yang digunakan, ada tes psikologi, angket penjurusanan, angket kepuasan pelanggan yang bekerjasama dengan HUMAS, ada AUM dan yang terbaru adalah IKMS, yaitu Instrumen Kebutuhan dan Masalah Siswa"

Penentapan personel, waktu, dan jenis instrumen akan sangat mendukung keberhasilan dari pengumpulan data. Setelah melalui kegiatan perencanaan, langkah selanjutnya yaitu pelaksanaan 
kegiatan pengadministrasian instrumen dan himpunan data. Pelaksanaan kegiatan di SMA N 1 Metro dilaksanakan setiap awal tahun pelajaran dan awal semester. Berikut petikan wawancara ( W.5/ I/41):

Pelaksanaan aplikasi instrumentasi dan himpunan data biasanya dilakukan pada awal tahun pelajaran (awal semester) dan disesester depan dilakukan lagi. Tetapi untuk data diri, dilakukan sekali pada awal tahun pelajaran,dan instrumen lain biasanya dilaksanakan sesuai kebutuhan, seperti angket penjurusan, angket minat, bakat, dan lain-lain

Lebih lanjut, informan menjelaskan bahwa dalam pelaksanaan kegiatan, penyekenggara kegiatan adalah guru BK. Berikut petikan wawancara (W.6/I/41), "Pelaksana kegiatan aplikasi instrumentasi dan himpunan data yaitu guru BK sendiri, tetapi bekerjasama dengan guru mata pelajaran untuk meminjam jamnya. Berdasarkan keterangan yang disebutkan oleh informan, dalam pelaksanaan kegiatan instrumentasi sangat diperlukan kerjasama dan dukungan dari pihak lain, seperti guru mata pelajaran. Sebagai bagian dari sistem sekolah, segala kegiatan BK hendaknya dilakukan dengan kordinasi dengan komponen lain. Tujuannya agar terjadi efektifitas dan tidak saling tumpang tindih.

Setelah dilakukan proses aplikasi instrumen, data yang telah terkumpul selanjutnya dilakukan analisis. Analisis data dilakukan oleh guru BK sesuai dengan jenis instrumen yang digunakan, dan juga data yang akan dikumpulkan. Setelah semua data dianalisa, maka selanjutnya data tersebut digolonggolongkan, kemudian dilakukan penghimpunan data. Data yang dihimpun adalah data yang rekevan dan data yang dapat dimanfaatkan. Berikut petikan wawancara (W.8/II/42): data data tersebut dipilih mana yang relevan, dan ada manfaatnya untuk siswa, seperti data pribadi, minat dan cita-cita, permasalahan yang dialami, maka data data tersebut disimpan dan dihimpun untuk dapat dimanfaatkan

Keterangan yang diberikan oleh guru BK SMA N 1 Metro didukung dengan data observasi. Melalui observasi (Ob.3/I/42), diperoleh data bahwa data yang telah diperoleh dari kegiatan aplikasi instrumentasi 
segera diolah dan dihimpun secara rapi dalam file-file.

Tahapan selanjutnya yang dilakukan adalah melakukan kegiatan evaluasi terhadap pengadministrasian instrument dan himpunan data. Berikut petikan wawancara (W.9///41): "Hal-yang dievaluasi biasanya manfaat dan efektifitas instrumen. Dalam Bimbingan dan Konseling, dikenal sangat banyak instrumen, namun penerapannya terkadang ada yang perlu disuatu sekolah, namun tidak disekolah lain. Nilai efektifitas dari instrumen itu yang sering menjadi bahan evaluasi oleh guru BK SMA N1 Metro. Keterangan informan tersebut, sesuai dengan data hasil observasi (Ob.5/I/42), “ Evaluasi terhadap kegiatan dilakukan mencakup efektifitas instrument, data yang diperoleh, dan juga kualitas instrument pengumpul data dan himpunan data. Jenis instrumen cukup banyak, namun yang digunakan yang rekevan dengan kebutuhan dan masalah siswa". Dengan demikian, dapat dinyatakan bahwa kegiatan evaluasi merupakan tahapan yang sangat penting untuk melakukan penilaian terhadap kegiatan yang dilaksanakan.

\section{Pemanfaatan Data Hasil Aplikasi} Instrumentasi Dan Himpunan Data

Bimbingan dan konseling di SMA N 1 Metro memanfaatkan data yang diperoleh dari hasil aplikasi instrumentasi dan himpunan data untuk pengembangan dan peningkatan kualitas dari program bimbingan dan konseling.

Data yang diperoleh dari kegiatan aplikasi instrumentasi dan himpunan data dimanfaatkan untuk dasar menyusun program bimbingan dan konseling. Berikut Petikan wawancara ( W.11/II/ 41), “ Data IKMS (salah satau Instrumen pengumpul data) menjadi dasar dalam penyusunan program $\mathrm{BK}$ di SMA N 1 Metro".

Lebih lanjut, informan menjelaskan selain untuk dasar dalam penyusunan program, data hasil aplikasi instrumentasi dan himpunan data digunakan sebagai referensi dalam memberikan materi layanan, sehingga materi sesuai dengan kebutuhan siswa. Berikut petikan wawancara (W.12/II/41)," 
Karena kami berdasarkan Need Assesment. Maka materi layanan berdasarkan dari data yang diperoleh dari aplikasi instrumentasi dan himpunan data. Dengan pemanfatan data tersebut, maka akan terhindar dari program yang sia-sia. Lebih lanjut informan menjelaskan (W.14/II/41): itulah prinsip "need assesment”. Contoh berdasarkan IKMS kami mengetahui layanan apa yang sangat dibutuhkan kelas X (siswa baru), sehingga layanan kita diberikan sesuai dengan kebutuhan mereka.

Selain dimanfaatkan dalam penyusunan program bimbingan dan konseling, penentu materi layanan BK, data hasil aplikasi instrumentasi dan himpunan data dimanfaatkan untuk pengembangan program bimbingan dan konseling. Pengembangan menyangkut aspek program, layanan, materi, dan efektifitas dari bimbingan dan konseling. Berikut petikan wawancara (W.13/II/41)," Dengan data yang tepat dan sesuai dengan kebutuhan siswa, kami sangat menghindari hal yang "mubazir" dalam membuat dan memberikan layanan, sehingga layanan BK dapat berkembang sesuai dengan kebutuhan siswa.

\section{Efektifitas Layanan Bimbingan}

\section{Dan Konseling}

Bimbingan dan konseling di SMA N1 Kota Metro pada tahun pelajaran 2009/2010 memanfaatkan kegiatan aplikasi instrumentasi dan himpunan data untuk meningkatkan efektifitas layanannya. Semua program dan materi layanan dibuat berdasarkan data hasil kegiatan aplikasi instrumentasi dan himpunan data.

Program yang dibuat sesuai dengan kebutuhan siswa, sehingga mampu membantu perkembangan diri siswa secara baik. Berikut petikan wawancara (W.16/II/41):

Layanan bimbingan dan konseling di SMA N1 Metro sangat mampu mendukung perkembangan peserta didik. Dengan layanan yang sesuai dengan kebutuhan mereka akan lebih mengetahui hal-hal yang mereka inginkan, lebih memahami diri sendiri, mampu memanfaatkan waktu, dan merencanakan masa depanya

Dengan program yang baik, materi layanan yang sesusai semakin menegaskan efektifitas dari layanan bimbingan dan konseling. 
Layanan bimbingan yang dibuat dan dilaksanakan oleh guru BK mampu membangun siswa untuk dapat beradaptasi dengan lingkunganya, dan tata nilai yang berlaku dimasyarakat. Guru BK di SMA N1 Metro tehnik memberikan layanan dilakukan dengan konseling perorangan, konsultasi, dan terkadang dengan memanggil siswa. Berikut petikan wawancara (W. 17/III/41):

guru BK sering memanggil siswa yang terlambat, sering melanggar peraturan, mereka diberi pemahaman dan bimbingan, secara perlahan mereka mampu merubah diri mereka sendiri. Mereka dapat beradaptasi dengan lingkungan dan tata nilai yang berlaku. Sebagai contoh, tingkat kedisiplinan siswa SMA N1 sangat tinggi atau baik

Di SMA Negeri 1 Metro Bimbingan dan Konseling memegang peranan yang sangat penting untuk membantu siswa mencapai perkembangan dirinya. Peran tersebut meliputi pemberian informasi diri, dan memberikan pemahaman akan potensi yang dimiliki siswa. Berikut petikan wawancara (W.18/II/41)," Peran Bimbingan dan Konseling dalam membantu siswa mencapai perkembangan yaitu dengan memberikan informasi diri, memberikan pemahaman diri akan potensi yang dimilkinya

Lebih lanjut, informan menjelaskan bahwa Bimbingan dan Konseling mampu membantu siswa untuk merancang masa depannya. Dengan melaksanakan bimbingan dan konsultasi dengan siswa yang mengalami masalah, akan akan mampu memberi pemahaman baru siswa. Berikut petikan wawancara (W.19/III/41):

Dengan menerima siswa yang akan berkonsultasi tentang masa depan mereka, lalu guru pembimbing memberikan gambaran dan nasehat yang mampu memberikan gambaran kepada siswa. Dan buktinya banyak siswa-siswa SMA N 1 yang mampu memasuki perguruan tinggi favorit dan memasuki dunia kerja yang diinginkanya

Data yang sama diperoleh melalui observasi (Ob.7/III/42), ” setiap permasalahan siswa dapat terentaskan dengan baik dan siswa memperoleh pemahaman baru".

Berdasarkan data pemaparan dan pembahasan di atas, kegiatan pelayanan bimbingan dan konseling yang dilakukan dengan 
memanfaatkan kegiatan aplikasi instrumen dan himpunan data menghasilkan efektifitas layanan yang cukup baik.

\section{KESIMPULAN DAN SARAN}

\section{Kesimpulan}

Kesimpulan penelitian sebagai berikut:

1. Kegiatan aplikasi instrumentasi di SMA N 1 Metro dilaksanakan dengan perncanaan yang baik, kerjasama dan koordinasi yang baik antara guru BK, wali kelas, dan guru mata pelajaran.

2. Dengan memanfaatkan kegiatan aplikasi instrumentasi dan himpunan data, layanan bimbingan dan konseling diSMA N 1 Metro dapat berjalan dengan efektif dan mampu membantu siswa.

3. Tingkat efektifitas layanan bimbingan dan konseling di SMA N1 Metro tahun pelajaran 2009/2010 cukup tinggi , Berdasarkan indikator keberhasilan layanan yang dilaksanakan oleh bimbingan dan konseling di SMA N1 Metro, seperti: a. Kemampuan siswa beradaptasi dengan norma dan nilai disekolah sangat baik

b. Tingkat kedisiplinan yang tinggi, dan pelanggaran siswa rendah

c. Keberhasilan dalam nelajar yang baik

d. Kemampuan merancang masa depam yang sangat baik dari siswa-siswa SMA N 1 Metro.

\section{Saran}

Setelah melakukan penelitian di SMA N1 Metro tentang tingkat efektifitas layanan bimbingan dan konseling melalui pemanfaatan kegiatan aplikasi instrumentasi dan himpunan data tahunpelajaran 2009/2010. maka penulis dapat memberikan saran untuk pengembangan bimbingan dan konseling, antara lain:

1. Peningkatan kualitas, efektifitas, dan relevansi dari instrumentinstrumen BK harus lebih diperhatikan demi memperoleh data yang tepat dari siswa.

2. Lebih meningkatkan kerjasama, dan koordinasi dengan guru mata pelajaran, dan wali kelas untuk memperoleh data 
perkembangan siswa baik belajarnya, maupun aspek lainya.

Prayitno. 2004. Himpunan Data. Padang: Universitas Negeri Padang

Prayitno. 2004. Aplikasi Instrumentasi. Padang: Universitas Negeri Padang

\section{DAFTAR PUSTAKA}

Depdiknas. 2006. Permendiknas no 22 tahun 2006 tentang Standar Isi, Http://konselingindonesia.com/22 /02/2010

Mulyadi, Agus. 2003. Dasar-Dasar Bimbingan Dan Konseling. Jakarta: Dirjen Pendidikan Dasar Dan Menengah.

Nurihsan, Achmad Juntika. 2006. Strategi Layanan Bimbingan Dan konseling. Bandung: Refika Aditama

Prayitno \& Erman Amti. 2004. DasarDasar Bimbingan Dan Konseling. Jakarta: Rineka Cipta.

Purwoko, Budi. 2008. Organisasi Dan Manajemen Bimbingan Konseling. Surabaya: Unesa University Press

Undang Undang Sistem Pendidikan Nasional 2003

Winkel, W.S. 2005. Bimbingan dan Konseling di Intitusi Pendidikan, Edisi Revisi. Jakarta: Gramedia

Yusuf, Syamsu \& A. juntika nurrihsan. 2006. Landasan Bimbingan Dan Konseling. Bandung : Rosda Karya. 